\title{
"UNHAPPILY EVER AFTER?" THE PROBLEM OF HELEN IN ODYSSEY 4
}

\author{
A Doyle (University of Johannesburg)
}

Book 4 of Homer's Odyssey contains two $\mu$ voor (stories) which reveal two, different "Helens": the first "Helen" is a self-portrait, Helen tells her guests a story about her encounter with Odysseus at Troy. The second "Helen" is revealed in a counter story told straight after hers by her husband Menelaus. This counter tale reveals how Helen nearly succeeded in betraying the Greek soldiers hidden in the Trojan horse. In Helen's story, she saves Odysseus' life and her silence and complicity result in Trojan losses. In Menelaus' story she threatens Odysseus' life as well as those others hidden inside the Horse almost bringing about the downfall of the Greeks and the victory of the Trojans and thus reversing the outcome of the Trojan War.

The questions to be asked are these: what is the purpose of these two portrayals of Helen? Indeed what is Helen doing in the Odyssey at all, after all, "The Iliad was Helen's poem; the Odyssey is Penelope's"? ${ }^{1}$ Why are we given this glimpse into the unquiet life of the reunited husband and wife and what does it portend, if anything, for the homecoming of Odysseus and his reunion with Penelope? This article examines the House of Sparta episode, and in particular its "Helen" stories, in an attempt to answer the above questions.

\section{Introduction}

In the Odyssey Troy has already happened; Troy is past: that is the single, great, unforgettable fact. At the same time, Troy continues to live on. Troy will not recede into the past: no one can forget it; it everywhere threatens to undo the primacy and coherence of the present. The Odyssey owes its particular poignancy to the way in which it gestures towards the past while refusing to acknowledge it — as something past (Gumpert 2001:25).

Early on in the Odyssey, Homer offers us an intriguing look at the domestic life of Helen of Troy, now once again Helen of Sparta - returned to her native home - and her husband, the warrior Menelaus. Helen's appearance in Books

$1 \quad$ Suzuki 1989:73.

Akroterion 55 (2010) 1-18 
4 and 15 of the Odyssey is structurally significant: Books 4 and 15 enclose the Telemachia: the journey Telemachus takes prompted by Athena to seek information about his father. The Spartan episode is told in two parts, flanking the wanderings of Odysseus. Book 4 precedes our meeting of Odysseus (which occurs in Book 5), while Book 14 has Odysseus finally return to Ithaca.

On first reading we are presented with a happy couple reunited after the scandal of Helen's adultery which tore the civilised world asunder culminating in the conflagration of Troy and the flight of the Trojan survivors. Helen, seemingly penitent but nevertheless spellbinding, and Menelaus, seemingly forgiving and indulgent, rule as Queen and King over an opulent Kingdom.

On closer inspection, however, we find that all is not what it seems. The Sparta interlude is riven with undercurrents of deep misery, loss and bitterness surfacing at various awkward moments and in dissonant narratives. This discussion seeks to evoke these moments of awkwardness and dissonance in order to apprehend and appreciate their complexity not just in themselves but also in terms of the epic as a whole.

The House of Atreus story is the story which initiates the action proper in the poem (Katz 1991:20) and has long been regarded as the foil for the plot of the Odyssey's narrative dealing as it does with the "unsuccessful" vó $\sigma \tau \varsigma$ (return) of Agamemnon from the Trojan War. In the words of Marilyn Katz, "... the story operates throughout as an alternative plot that threatens to attract the Odyssey into its orbit" (1991:30). The House of Sparta story reveals the results

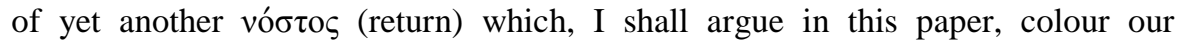
experience and expectations of Odysseus and Penelope's reunion in a different and more subtle way than the dark tale of Clytemnestra's sexual betrayal and mariticide.

\section{Setting the scene}

Telemachus and his companion Pisistratos arrive in Sparta with the purpose of discovering information about the lost hero Odysseus' whereabouts. Their arrival coincides with the celebration of a double wedding: that of Hermione (daughter of Menelaus and Helen) to Neoptolemus (the son of Achilles) and Megapenthes (illegitimate son of Menelaus and a palace slave woman) to a Spartan daughter of Alector (4:3ff). ${ }^{2}$ The two strangers are received warmly

The fact of Megapenthes' illegitimacy introduces the first of many notes of discomfort disturbing the plush tableau of "rightness" about palace life in Sparta. This, according to Suzuki 1992:63, strikes a melancholy note, "Menelaus' relationship with the mother of 
by the king who welcomes them and ensures they are refreshed and fed before attempting to discover their identities or purpose for being there. This is correct accordance to the customs and practice of $\xi \varepsilon v i ́ a$ (the institution of guest-host relationships). All seems in order but soon things start to go wrong - certainly from a hospitality point of view. Once the young men have finished eating Telemachus quietly marvels to his companion on the lavish display of wealth in the palace (4:79-84) remarking somewhat naively that Zeus' halls in Olympus must look the same. Menelaus overhears this, and, while he concedes his unrivalled wealth among mortals (78-81), his reply reveals some disturbing truths concerning the price for the acquisition of his riches. $^{3}$

Menelaus reveals the melancholy that afflicts him: despite his wealth, he cannot forget the painful memories of his past - all those comrades who died at Troy, the murder of his brother Agamemnon and (as we shall see) the disappearance of his great friend Odysseus. These are all mentioned as the

Megapenthes (whose name means "great sorrow") points to the disruption of conjugal ties brought about by Helen's elopement with Paris”. See also de Jong 2001:91 commenting on lines 3-19. Translations of the Odyssey are taken from Fagles 1996 (slightly adapted at times).

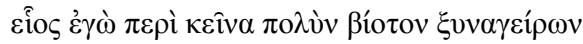

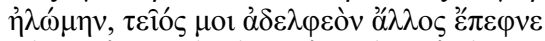

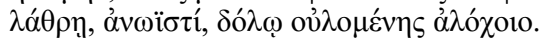

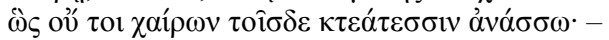

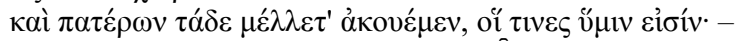

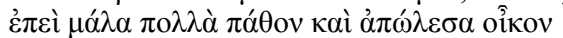

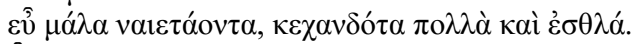

ஸ่̂

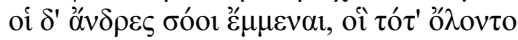

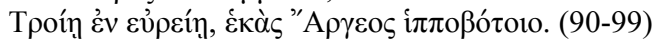

But while I roamed those lands, amassing a fortune, a stranger killed my brother, blind to the danger, duped blind thanks to the cunning of his cursed, murderous queen!

So I rule all this wealth with no great joy.

You must have heard my story from your fathers, whoever they are - what hardships I endured,

how I lost this handsome palace built for the ages, filled to the depths with hoards of gorgeous things.

Well, would to god I'd stayed right here in my own house with a third of all that wealth and they were still alive, all who died on the wide plain of Troy those years ago ... (100-110) 
source of his pain. But the most painful memory of all, which must be Helen's betrayal and elopement with Paris, he does not mention explicitly. As if too painful to articulate he mentions his absence from his palace followed by the imprecation ... would to god I'd stayed right here in my own house / with a third of all that wealth and they were still alive (108). When remembering Agamemnon's death, he attributes it as thanks to the cunning of his cursed, murderous queen, a periphrasis that could apply as well to Helen, sister of Clytemnestra (Suzuki 1989:64). ${ }^{4}$

Here Menelaus suggests that the most important event of his life was his betrayal by Helen; his identity is solely that of a betrayed husband. Despite the Achaean victory and Helen's return, despite the riches gained in his seven years of wandering before returning to Sparta, Menelaus cannot be content, since he is unable to refrain from looking backward to the traumatic disruption of his domestic peace and to the war that came in its wake. Incapable of living in the present or looking forward to the future, Menelaus instead derives a certain pleasure in mourning and dwelling on the past ... (Suzuki 1989:64).

Menelaus then remembers Odysseus as the comrade he grieves over the most (100-112). He tells Telemachus that he feels relentless, heartbreaking grief

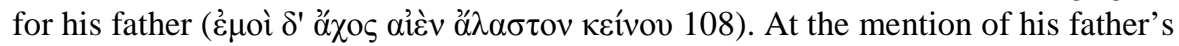
name, Telemachus breaks down in tears leaving Menelaus at a loss:

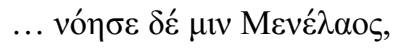

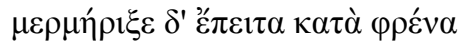

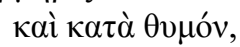

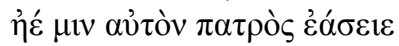

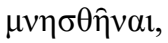

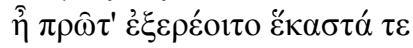
$\pi \varepsilon i \rho \eta ́ \sigma \alpha i \tau o \quad(116-119)$
Menelaus recognised him at once but pondered whether to let him state his father's name or probe him first and prompt him step by step (4.131-133)

And the narrative makes space to allow for the much anticipated arrival of Helen. She arrives on the scene to find a stranger, as yet unidentified, weeping

Helen can be viewed as an example of "[a] cursed, murderous queen" on a grand, impersonal scale, while her sister functions on a smaller, personal scale - within that of the oikos: Helen's actions lead to the destruction of nations, citadels, societies, Clytemnestra's to the destruction of her husband, family unit, and the political structure of Argos. 
inconsolably, clutching his robe in front of his face while Menelaus her husband stands by dithering helplessly. ${ }^{5}$

Helen appears here for the first time in the epic. Our indication that she may be different from the Helen of the Iliad is her link with the goddess Artemis. The virginal goddess is a far cry from Aphrodite to whom Helen is likened in Iliad Book 3 (154-158). ${ }^{6}$ Artemis is the least likely approximation for Helen and thus it has been suggested:

The comparison may be a way of introducing from the beginning of this scene a subtle and, perhaps, comic tension into the figure of Helen, a gap between what Helen appears to be (chaste as Artemis, a happy homemaker for Menelaus) and what we know her to be (Gumpert 2001:34).

Helen here seems changed, more aligned with her plainer cousin Penelope than Aphrodite's bewitching earthly representative. Indeed we are reminded more of Penelope as the scene progresses for Helen is represented as weaver and a hostess who alleviates the social awkwardness and identifies their guest:

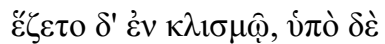

$\theta \rho \hat{\eta ิ v v \varsigma ~ \pi o \sigma i ̀ ~ ท े ~}$

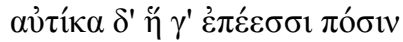

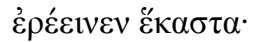

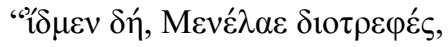

oli $\tau \mathrm{iv \varepsilon}$ oí $\delta \varepsilon$

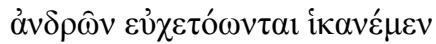

$\dot{\eta} \mu \varepsilon \dot{\tau \varepsilon \rho o v} \delta \hat{\omega}$
Helen leaned back in her chair, a stool beneath her feet, and pressed her husband at once for each detail:

"Do we know, my lord Menelaus, who our visitors claim to be, our welcome new arrivals?

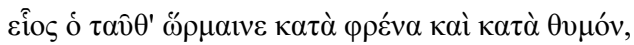

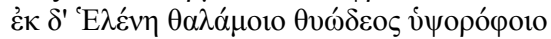

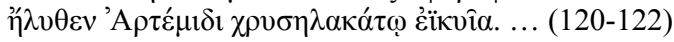

While he debated all this now within himself, Helen emerged from her scented, lofty chamber -

striking as Artemis with her golden shafts - (135-137)

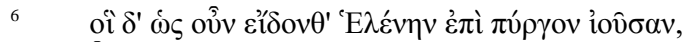

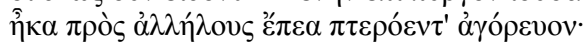

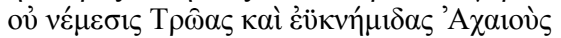

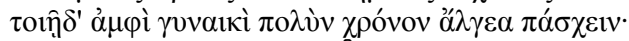

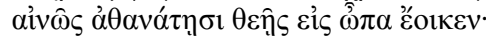




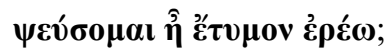

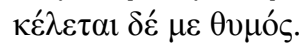

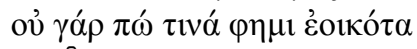

$\hat{\omega} \delta \varepsilon$ i $\delta \dot{\varepsilon} \sigma \theta \alpha \mathrm{l}$

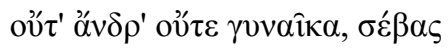

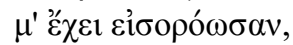

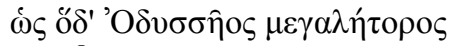

vî हैoเ $\varepsilon$,

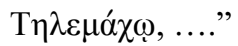

(136-144)
Should I lie or speak the

truth ? ${ }^{7}$ My heart compels me

For I must say I've never seen

such a likeness,

neither in man nor woman -

I'm amazed at the sight.

To the life he's like the son of great Odysseus, surely he's Telemachus!"

(4.151-159)

Helen recognises Telemachus immediately and in her opening speech she draws her audience's purposeful attention to her perceptive abilities and narrative control. When she recognises Telemachus as the son of Odysseus, she asks, Should I lie or should I speak the truth? (4.140). ${ }^{8}$ This is surely an odd thing to say, for it undercuts the delicately built up portrait of the "good" Helen — all that has gone before is immediately called into question: if Helen can choose between lies and truth, consciously - how truthful is her portrait? Yet Helen does speak the truth, in so far as she confers recognition of Telemachus as Odysseus' son - an important aspect of his "coming of age" process.

Galvinised out of his stupefaction by his wife, Menelaus acknowledges the likeness of Telemachus to his famous father and welcomes his guests. He remembers Odysseus as his "dearest friend" (163-203) and laments his failure to return home. ${ }^{9}$ At this, the court: Helen, Telemachus, Menelaus and Pisistratus break down in tears. When they finish weeping, Menelaus sets aside time for himself and Telemachus to talk the following day and exhorts his guests to prepare for supper. While supper is being prepared, Helen steps in once again and takes control over the situation, announcing that she will tell them a story. But before she tells her tale, she does a curious thing:

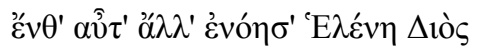

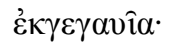

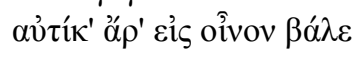

\author{
Then Zeus' daughter Helen \\ thought of something else. \\ Into the mixing bowl from
}

7 Translation and emphasis my own.

8 Stanford on line 140 (1967:272-273), regards this dilemma of Helen's merely as one of tact due to her sensitivity to Telemachus' situation but he does not connect it with the veracity of her story.

9 De Jong 2001:94 notes the guilt of Menelaus commenting on lines 76-112 she remarks, "In his [Menelaus'] case grief is mixed with guilt, in that he is only too aware that the other Greeks exerted themselves because of him". 


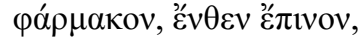
$v \eta \pi \varepsilon v \theta \dot{\varepsilon} \varsigma \tau^{\prime} \alpha^{\prime} \chi 0 \lambda o^{\prime} \tau \varepsilon, \kappa \alpha \kappa \hat{\nu} v$

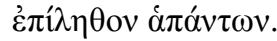

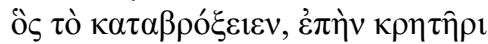

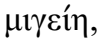

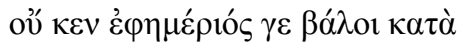

$\delta \alpha ́ \kappa \rho v \pi \alpha \rho \varepsilon \imath \hat{\omega} v$,

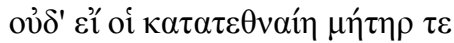
$\pi \alpha \tau \eta \dot{\rho} \tau \varepsilon$,

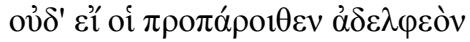

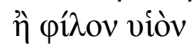

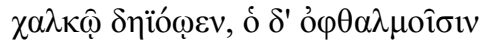

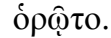

(219-226) which they drank their wine she slipped a drug, " no pain", dissolving anger, magic to make us all forget our pains ...

No one who drank it deeply, mulled in wine, could let a tear roll down his cheeks that day, not even if his mother should die, his father die, not even if right before his eyes some enemy brought down a brother or darling son with a sharp bronze blade. $(243-251)^{10}$

Thereby Helen rescues the occasion, which threatened to turn into a session of communal grieving for the past, inappropriate for a welcoming feast and turns it to one of diversion and entertainment by storytelling. It is here, that Helen's portrayal begins to change, or widen to include elements of a darker nature. Helen the Фарнакís (Sorceress) has much more in common with the immortal enchantresses than with faithful Penelope. Here is a version of the Dread Goddess a Calypso or Circe who inhabits the epic in her multifarious forms. ${ }^{11}$ Before we hear the tale we know that Helen's tale will be "detoxified" (Bergren 1981:207) so that it shall evoke no feelings of pain or loss in those who hear it. "Mixing her drugs, interpreting omens, captivating the assembled company, the Homeric Helen is both a sorceress and a salve, intoxicating to the last" (Hughes 2005:233). And we wonder — is Helen drugging her audience in order to still the painful memories tactlessly evoked by Menelaus or in order to prime them for the "diversion" she is about to provide?

10 Bettany Hughes identifies the drug as opium, which, when mixed with wine (alcohol) becomes pure laudanum (2005:233) but in her notes admits that it could also have been mandragora, which when mixed with wine produces a trance-like state (p.393 note 26). See also Heubeck et al.:206 commenting on lines 220ff.

11 See Gumpert 2001:41 on Helen as Egyptian sorceress. "The description of Helen's drug contains hints of the same sexual aura as surrounded Circe's drug, but it not only makes men forget their nostos, as Circe's did, but makes them forget all their problems" (Wohl 1993:33). 


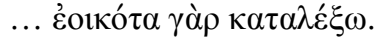

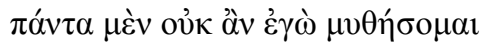

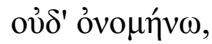

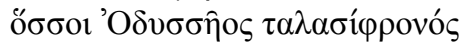

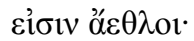

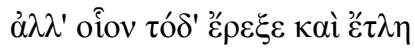

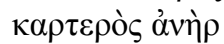

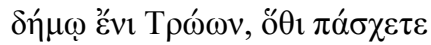
$\pi \eta \dot{n} \mu \alpha \tau^{\prime}$ 'A $\chi \alpha$ เoí.

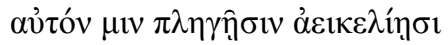
$\delta \alpha \mu \alpha ́ \sigma \sigma \alpha \varsigma$,

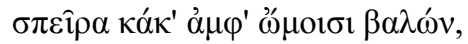

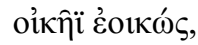

${ }_{\alpha} \alpha \delta \rho \hat{\omega} v \delta v \sigma \mu \varepsilon v \varepsilon \dot{\varepsilon} \omega v \kappa \alpha \tau \varepsilon \dot{\delta} \delta v \pi o ́ \lambda \mathrm{v}$

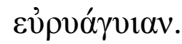

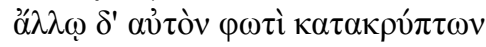

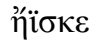

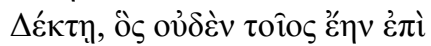

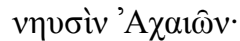

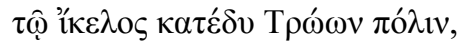

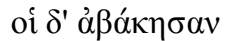

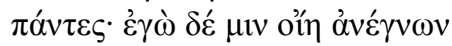

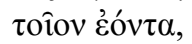

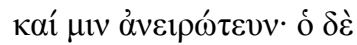

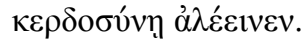

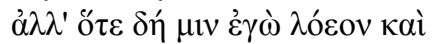

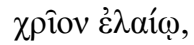

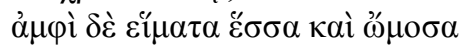

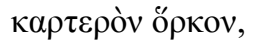

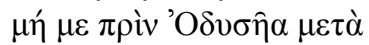

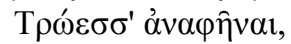

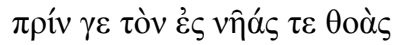

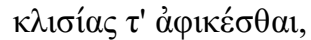

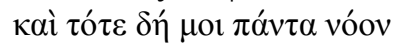
$\kappa \alpha \tau \dot{\varepsilon} \lambda \varepsilon \xi \varepsilon \nu{ }^{\prime} \mathrm{A} \chi \alpha \iota \hat{\omega} \nu$.
... "I will tell something perfect for the occasion. ${ }^{12}$

Surely I can't describe or even list them all, the exploits crowding fearless Odysseus' record, but what a feat that hero dared and carried off in the land of Troy where you Achaeans suffered!

Scarring his own body with mortifying strokes, throwing filthy rags on his back like any slave,

he slipped into the enemy's city, roamed its streets all disguised, a totally different man, a beggar, hardly the figure he cut among Achaea's ships.

That's how Odysseus infiltrated Troy, and no one knew him at all ... I alone, I spotted him for the man he was, kept questioning him - the crafty one kept dodging. But after I'd bathed him, rubbed him down with oil, given him clothes to wear and sworn a binding oath not to reveal him as Odysseus to the Trojans, not till he was back at his swift ships and shelters,

12 Emphasis mine. 


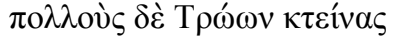

$\tau \alpha \nu \alpha \eta \dot{\kappa \varepsilon i ̈ ~} \chi \alpha \lambda \kappa \hat{\omega}$

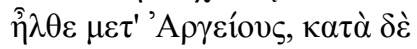

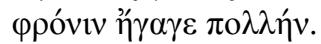

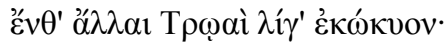

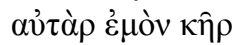

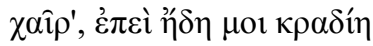

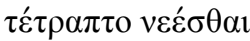

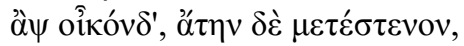

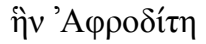

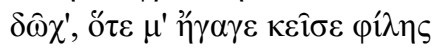

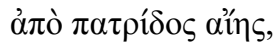

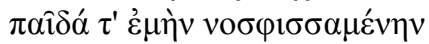

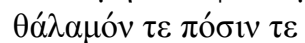

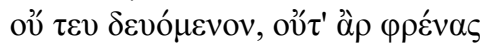

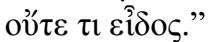

(239-264) then at last he revealed to me, step by step,

the whole Achaean strategy.

And once he'd cut

a troop of Trojans down with

his long bronze sword,

back he went to his comrades,

filled with information.

The rest of the Trojan women

shrilled their grief. Not I:

my heart leapt up -

my heart had changed by now

- I yearned

to sail back home again!

I grieved too late for the

madness

Aphrodite sent me, luring me

there, far from my dear land,

forsaking my own child, my

bridal bed, my husband too,

a man who lacked for neither

brains nor beauty" (269-296)

The tale, at face value, deals with an incident during the Trojan War when Odysseus infiltrates the enemy city in disguise presumably on a scouting mission. The tale is told, ostensibly, to highlight the brilliance of Odysseus. ${ }^{13}$ On closer inspection, the tale works harder to convert our perceptions about Helen. It presents an image of Helen who is pro-Greek, a secret enemy of the Trojans who helps Odysseus the spy to take Trojan lives by stealth. She is the only one who penetrates his disguise and we learn that she too is in disguise in the sense that her heart has changed sides yet again and she rejoices at the success of the Greek mission while dissembling Trojan partisanship. Helen's audience are seeing her in a new light, a positive light as the saviour of their cleverest hero. "How appealing", says Anne Bergren, "for Menelaus, Telemachus and Pisistratus to be able to see Helen, the object of all the sacrifices they were just lamenting, as a victim of Aphrodite's machinations" (1981:208).

13 Scholars have remarked on how Helen forecasts the epic fame Odysseus attains later in the epic when he penetrates his own palace similarly disguised in order to regain his throne and destroy his enemies. See Bergren 1981:208. 
In this light the story itself takes on the form of a sort of spell or enchantment which immediately casts doubt upon its veracity. It is as if Helen is hypnotising her audience! As if she wishes them to change their perceptions about her, for after all, and, from a certain point of view, it is Helen's fault that Odysseus is missing, that Telemachus has grown up without a father, that Penelope is at home besieged by a hundred suitors - the Odyssey is Helen's fault!

One must also wonder what is there in the narrative that requires such a powerful painkiller? While her immediate audience is drugged into acceptance of a dazzlingly clever, dissimulative Helen, loyal to their cause and enamoured once again of her first husband, we readers pause, puzzled and we try to make sense of her tale: how did this beggar Odysseus come to be received at the Trojan court and bathed by none other than Helen herself? What was Helen doing bathing a naked beggar? "14 "Why did Odysseus permit himself to be bathed, anointed and clothed by a woman whose earlier recognition and questioning he had to elude?" (Bergren 1981:208). It has been suggested that a depiction of Odysseus' success achieved by violating the laws of $\xi \varepsilon v i ́ \alpha$ was potentially shameful to Telemachus or that the image of Helen bathing a naked Odysseus might be painful to Menelaus or even an embarrassment to Telemachus. ${ }^{15}$

There is surely a fracturing and a fragmenting of the truth at work here.

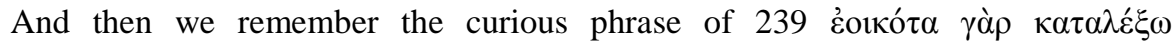
(I shall tell something perfect for the occasion) the phrase with which she begins

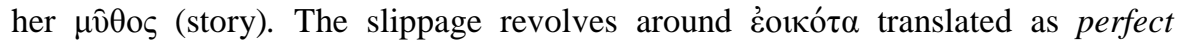
for the occasion; it can also mean fitting, plausible or likely: not necessarily true!

This ambiguity is also present in the word $\mu$ vi $\theta$ ors (stories) the term Helen employs when she says let us warm our hearts with stories (239). For $\mu \hat{v} \theta$ o $\varsigma$ (story) can be applied to any speech or set of words; while, at the same time a $\mu \hat{v} \theta 0 \varsigma$ is a

14 While it is true that the bathing of guests was heroic custom in the Homeric world and that honoured guests were bathed by female members of the host's family and not servants, (such as Nestor's daughter bathing Telemachus in 3:464), it seems unlikely that Helen's duties would encompass bathing beggars or strangers who found themselves at the Trojan palace. It seems more plausible that this duty would fall to the female servants as we see with Odysseus himself when, still in his beggar's disguise, Penelope calls for her serving women to bathe him (19:317-323), she does not offer to do it herself.

15 Bergren 1981:209 hints that Helen's story allows Telemachus tantalising glimpses of an erotic scene between her and Odysseus calling it a subtly staged seduction of her young guest. 
legend, a story, a myth, and thus sits diametrically opposed to $\lambda$ ó $\gamma \circ \varsigma$ (verbal account or word) which implies truth or historical veracity. ${ }^{16}$

Helen's drug cocoons her audience from the fractures in her story while those of us unaffected by such sorcery start to question her "plausible truth".

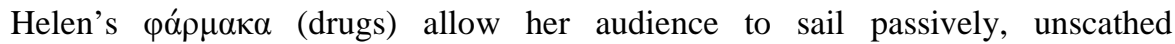
through the problems in her tale, receiving it without comment or objection. Menelaus then counters with a $\mu \hat{v} \theta 0 \varsigma$ (story) of his own in the form of a doublet or rival tale.

Menelaus' story

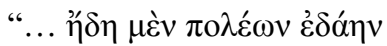

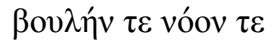

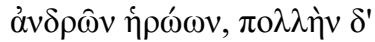

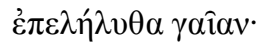

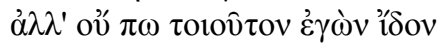
ỏ $\varphi \theta \alpha \lambda \mu 0 \hat{\sigma} \sigma \mathrm{v}$

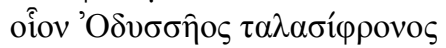

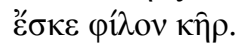

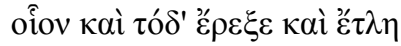

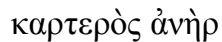

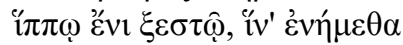

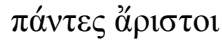

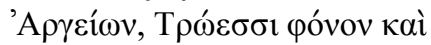

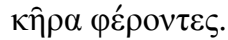

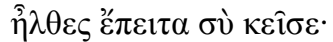

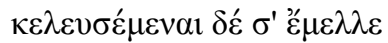

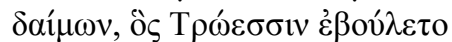

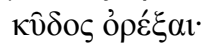

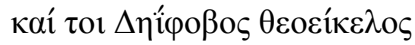

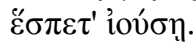

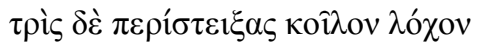

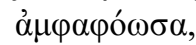

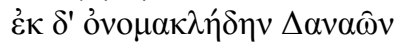

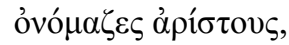

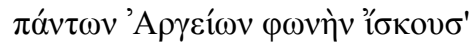

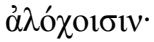

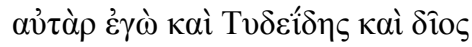

“... What a feat the hero dared and carried off

in the wooden horse where all our best men encamped, our champions armed with bloody death for Troy ... when along you came, Helen roused, no doubt,

by a dark power bent on giving Troy some glory, and dashing Prince Deiphobus squired your every step.

Three times you sauntered round our hollow ambush, feeling, stroking its flanks, challenging all our fighters, calling each by name yours was the voice of all our long-lost wives!

And Diomedes and I, crouched tight in the midst with great Odysseus, hearing you singing out, were both keen to spring up and sally forth

or give you a sudden answer from inside,

16 Gumpert 2001:37-38. 


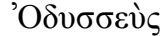

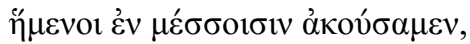

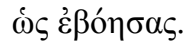

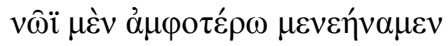

ор $\mu \eta \theta \varepsilon \dot{v} \tau \varepsilon \varsigma$

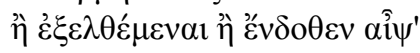

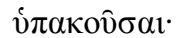

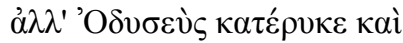
है $\sigma \chi \varepsilon \theta \varepsilon v$ i $\varepsilon \mu \varepsilon \dot{\varepsilon} v \omega \pi \varepsilon \rho$.

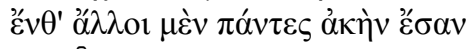

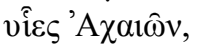

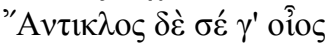
$\dot{\alpha} \mu \varepsilon \dot{i} \psi \alpha \sigma \theta \alpha \mathrm{l} \dot{\varepsilon} \pi \varepsilon \varepsilon_{\varepsilon \sigma \sigma l v}$

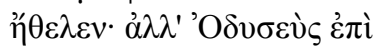

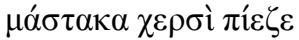

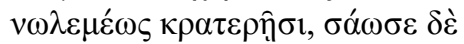

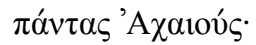

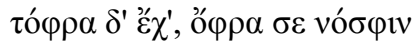

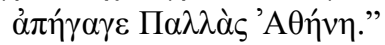

(265-289) but Odysseus damped our ardour, reined us back.

Then all the rest of the troops

kept stock-still,

all but Anticlus. He was hot to salute you now

but Odysseus clamped his great hands on the man's mouth and shut it, brutally - yes, he saved us all, holding on grim-set till Pallas Athena lured you off at last". (304-324)

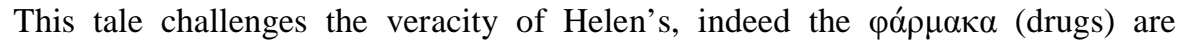
required to work harder in order for this one to be ingested without a reaction. Menelaus' story purports, as Helen's did, to celebrate Odysseus telling of another victory through disguise and cunning. But Menelaus' story is reveals as much about Helen as Odysseus. Here we have another Helen, Helen "in her full malignant colours": ${ }^{17}$ she is on her third husband, Deiphobus, brother of Paris whom she married after Paris died, trying to coax the Greek soldiers from the Trojan Horse using her uncanny skill in ventriloquy. Helen's trick encourages further her dubious association with the other Dread goddesses of the epic Calypso and Circe who with their vocal allure and heady cocktails are responsible not merely for detarding the hero but for endangering his life.

Does Menelaus' story make Helen's story a lie? Which version of Helen is true? Who is more compelling, Helen or Menelaus? Why does Menelaus tell this story? Lilian Doherty, in answer to these questions says the following:

17 Suzuki: 1992: 90. 
The clear implication of Menelaus' story is that Helen's story was false - that her "change of heart" is an invention not only for her present audience but also for Odysseus, her audience in the story (when she protested to him in Troy that she was his ally). [...] In the episode itself, Menelaus' tale is given somewhat greater weight than Helen's by its position: It serves as an implicit rebuttal, which Helen has no chance to contest (1995a:86).

Yet other scholars, finding no evidence for this - and indeed there is none - thanks to Helen's drugs - argue against Menelaus undercutting his wife:

I do not believe that Menelaos is criticizing Helen, or rebuking her, or undercutting her, or implying that she has lied. First of all, he congratulates Helen on her story (266); and second, he has chosen an everyday conversational strategy that generally indicates supportiveness: that is, he tells a story which complements that of Helen. If Menelaos were being critical of his wife, then his compliment at 266 is meaningless and his strategy in telling the story he tells is malicious. Menelaos has several weaknesses of character, but malice is not one of them (Minchin 2007:278 note 106).

Some scholars feel that "Menelaus' tale implicitly addresses Helen to unmask and rebuke her treachery to Odysseus - and to himself. In so doing, he also counters the intended effects of her own tale and issues an implicit warning to male members of her audience". ${ }^{18}$ Others see Menelaus' tale as evidence of Helen's magic recoiling upon its practitioner. ${ }^{19}$ Yet I do not see how it recoils — his tale has a limited impact — it is dulled by Helen's drug.

\section{Menelaus' grief}

The clue to making sense of all this scholarly contention (and there is much of it) lies, in my opinion, in Menelaus' grief. Helen's use of the drug, presented so prosaically here prompts us to ask whether she doesn't use this drug regularly. Suddenly Menelaus' admission of the grief that still grips him earlier in the book, takes on more significance. The drug is no mild palliative to ease the pain, rather, its effects, termed by some as "grotesque" (Worman 2001:31) dull the emotions to such an extreme that the witnessing of the murder of a sibling would not evince a tear. Helen's drug enables her husband and guests to enjoy their evening.

18 Doherty 1995b:84.

19 See Bergren's discussion 1981:210 ff. 
Her remedy is also instrumental in her control of the narrative: "it serves as an essential complement to her control of verbal interaction and storytelling (Worman 2001:31) and, I would suggest, how not only hers, but also that of her husband's is received.

Helen anticipates the negativity of Menelaus' tale - her drug is meant to dull the reception of both $\mu$ v́ $\theta$ or (stories). After all, it is not for nothing that Helen is shown highly perceptive in her ability not only to recognise Telemachus whom she had never set eyes on; but to penetrate Odysseus' disguise in Troy — she also reads the future interpreting an omen propitious for Odysseus' homecoming upon Telemachus' departure. ${ }^{20}$

And then there are those who regard these paired tales "as a collaborative gesture, a means of displaying mutual understanding and connectedness" (Minchin 2007:277). ${ }^{21}$ We would be hard pressed to find evidence for a prevailing atmosphere of domestic contentment in book 4 as a whole. Indeed, in my opinion, these tales represent with a startling clarity the mutual mis-understanding and dis-connectedness of Helen and Menelaus which we shall speak more about later.

For all our puzzlement, our disquietudes are not echoed by the listeners themselves - Telemachus' response is evidence of the success of

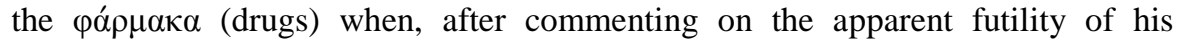
father's heroism in the context of his endeavours to return home, he signals that he is ready to retire for the night. For all his "clear-sightedness", Telemachus fails to perceive the inherent problems in the tales, he responds to them as if they were simply illustrations of his father's heroism, nothing more $(290-295) .^{22}$

The function of the Spartan interlude in the epic

[A]s foreshadowings of the situation Odysseus will face on Ithaca, the tales of Helen and Menelaus offer a choice of two courses of action:

20 See Odyssey 15:171-178. See Austin 1975:187-189.

21 Austin 1975:188-89 interprets the paired tales as an example of "marital homophrosyne" between the reunited couple. A direct contradiction of this is Winkler's statement, "A charming illustration of an unlikeminded couple is Menelaos and Helen" (1990:140).

22 Telemachus does seem recovered from his weeping of earlier although he is still somewhat gloomy. 
Odysseus can reveal himself to Penelope, as he did to Helen in Troy, or he can resist the temptation to do so, as he did inside the Horse when Helen imitated his wife's voice. In choosing the second of these options, Odysseus acts on the presumption of female treachery planted by Menelaus' story and enhanced by the story of Agamemnon and Clytemnestra (Doherty 1995b:60).

The juxtaposition of Helen's story and Menelaus' leaves us disquieted but alert. ${ }^{23}$ Despite the tingling of disquiet, the audiences both internal and external remain under Helen's spell and no negative emotions surface. We are left feeling that something is not quite right at the court of Sparta, that all is not what it seems between this king and queen.

Helen and Menelaus' tales reveal more about themselves than about their ostensible subject, Odysseus. Helen's tale is about Helen. She tells her story to re-create herself, recollecting in order to characterise or, more accurately, re-characterise. Helen is doubtless aware that the ambiguous "Iliadic" Helen looms large in the minds of her listeners, those for whom the Trojan War is recent history. Here she has an audience of the younger generation, an audience who wasn't there. This is her opportunity to re-tell herself. Menelaus' tale represents the trauma of the past: Helen's change of sides, the war that ensues. It shows Menelaus is still haunted, by it, thus reinforcing his admission to Telemachus earlier of his constant grieving. ${ }^{24}$

The Spartan episode is a mise en abîme - the artistic procedure of interior duplication. The situation at Sparta comments on the vó $\sigma \tau$ or (homecomings) and the psychological or emotional dangers surrounding these. ${ }^{25}$ Helen's magic and Menelaus' damaged spirit — hang over the reunion between Odysseus and Penelope. Homer links these cleverly in the famous and controversial

23 De Jong 2001:102 discusses some of the narratological functions of the paired stories in her commentary on lines 234-289 of book 4 .

24 Heubeck et al.1988:200 comment persuasively on the "prevailing mood of melancholy reminiscence" in the Sparta interlude. See their commentary on lines 120ff. De Jong 2001:101 describes both Helen and Menelaus as being still in the grip of their past implying that they are both in need of Helen's drug. While I think it is clear that Menelaus is haunted by the traumas of the past, I have argued that Helen is more concerned with self-reinvention. On De Jong's implication regarding the drug it would be unprecedented for Helen the Pharmakis to drink her own drugs - sorceresses administer their potions they do not partake of them.

25 As opposed to the physical dangers which Clytemnestra's exemplum warns us (and indeed, Odysseus himself) of. 
"Helen apology" delivered by Penelope in Book 23. ${ }^{26}$ This is the moment "where Penelope instances Helen's betrayal of Menelaus as the story that might have been her own ..." (Katz 1991:187).

\section{Conclusion}

We leave book 4 sensible of the remarkably dominant position that Helen occupies in the royal house of Sparta: "she is the one who controls the muthoi in the house ..." (Wohl 1993:32). Not only does she seem to take control of narratives (being one of four privileged women narrators within the epic), she takes it upon herself to welcome her guests by offering them $\xi \varepsilon v i ́ \alpha$ (guest friendship) while Menelaus dithers (4.116-119), she creates the wealth of the household with her spinning and the gifts of $\xi \varepsilon v i ́ \alpha$ (4.125 ff). It must also be remembered here that Helen's position is matrilocal in the sense that Sparta is her home, not Menelaus'. But the epic renders her far more than just powerful Queen, she is Sorceress, Narrator and Prophetess. Helen is the link between the dangerous immortal seductresses: Calypso, Circe and the Sirens and faithful Penelope - her cousin. Helen is both immortal and mortal, enchantress and hostess, wife, weaver and story-teller, giver of gifts. ${ }^{27}$ But for all her powers both pharmaceutical and verbal, it is the damaged figure of Menelaus who touches us, whose past suffering has so scarred his present.

We are left with a king mired in the past, guilt ridden and depressed and with a Helen who changes as one attempts definition - the first of the "post-

26

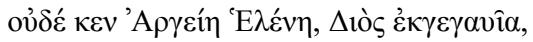

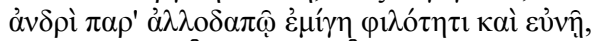

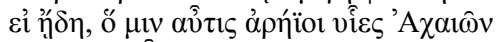

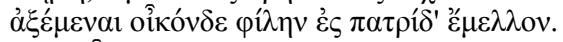

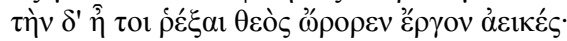

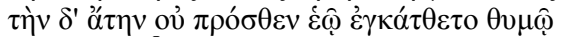

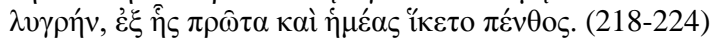

Remember Helen of Argos, Zeus' daughter would she have sported so in a stranger's bed if she had dreamed that Achaea's sons were doomed to fight and die to bring her home again? Some god spurred her to do her shameless work. Not till then did her mind conceive that madness, blinding madness that caused her anguish, ours as well. (246-252)

27 In Book 15 (123-130) Helen gives Telemachus a robe woven by her own hands for his future bride to wear, she calls it a keepsake of Helen ( $\mu \nu \eta \hat{\mu}{ }^{\prime}$ 'E $\left.\lambda \varepsilon \dot{v} \eta \varsigma\right)$. 
Iliadic" Helens who will elude us in our attempts to write her down and delude us into thinking we can understand her.

Homer was a master of representing the human condition. Despite the happy reunion of Penelope and Odysseus, Homer has shown us an alternative model in Agamemnon and Clytemnestra which scholars have focused on as the foil, or negative version of events. Between these two extreme models of vó $\sigma \tau \varsigma$ (homecoming) lies the exemplum of yet another husband and wife which mediates between the paradigm of Odysseus and Penelope on the one hand and Agamemnon and Clytemnestra on the other.

And so a careful reader sees that the Odyssey doesn't end in one colourful reunion of two like-minded protagonists but rather how the joy is darkened by the reference to Helen we are tinged with the same sadness that seems to have caught Menelaus in her cold hand. One can never go back ... nothing is ever the same.

\section{BIBLIOGRAPHY}

Austin, N 1975. Archery at the dark of the moon: Poetic problems in Homer's Odyssey. Berkeley California: California University Press.

Bergren, A 1981. Helen's 'good drug': Odyssey IV 1-305. In Contemporary literary hermeneutics and interpretation of classical texts. Kresic, S (ed.) Ottawa: Ottawa University Press.

Bergren A 2008. Weaving truth: Essays on language and the female in Greek thought. Cambridge Massachusetts: Harvard University Press.

De Jong, I 2001. A narratological commentary on the Odyssey. Cambridge: Cambridge University Press.

Douglas Olson, S 1989. The stories of Helen and Menelaus (Odyssey 4.240-289) and the return of Odysseus. The American Journal of Philology, 110.3: 387-94.

Dougherty, L 1995a. Siren songs: Gender, audiences, and narrators in the Odyssey. Michigan: Ann Arbor, University of Michigan Press.

Dougherty, L 1995b. Sirens, muses, and female narrators in the Odyssey. In Cohen, B The distaff side: Representing the female in Homer's Odyssey. Oxford \& New York: Oxford University Press.

Fagles, R (trans.) 1990. Homer: The Iliad. UK: Penguin.

Fagles, R (trans.) Homer: The Odyssey. UK: Penguin.

Gumpert, M 2001. Grafting Helen: The abduction of the classical past. Wisconsin: University of Wisconsin Press.

Heubeck, A West, S \& Hainsworth, J B 1988. A commentary on Homer's Odyssey Volume 1. Oxford: Clarendon Press.

Hughes, B 2005. Helen of Troy: Goddess, princess, whore. UK: Jonathan Cape. 
Katz, M A 1991. Penelope's renown: Meaning and indeterminacy in the Odyssey. Princeton, New Jersey: Princeton University Press.

Minchin, E 2007. Homeric voices: Discourse, memory, gender. Oxford: Oxford University Press.

Stanford, W B 1967. The Odyssey of Homer Volume 1. London: Macmillan.

Suzuki, M 1989. Metamorphoses of Helen: Authority, difference, and the epic. Ithaca \& London: Cornell U.P.

Winkler, J J 1990. The constraints of desire : The anthropology of sex and gender in Ancient Greece. New York \& London: Routledge.

Wohl, V J 1993. Standing by the stathmos: The creation of sexual ideology in the Odyssey. Arethusa 26:19-50.

Worman, N 2001. This voice which is not one: Helen's verbal guises in Homeric Epic. In Mclure L \& Lardinois A (eds.) Making silence speak: Women's voices in Greek literature and society. Princeton New Jersey: Princeton University Press. 